\title{
KINERJA JAKARTA ISLAMIC INDEX DIMASA PANDEMI COVID-19 TAHUN 2020
}

\author{
Syafaat Muhari ${ }^{1}$
}

\begin{abstract}
Abstrak
Penelitian ini bertujuan untuk mengukur dampak Covid-19 terhadap Kinerja Jakarta Islamic Index dengan membagi pengukuran menjadi tiga periode. Periode Desember 2019 - Februari 2020 yang merupakan periode dimana Covid-19 sudah muncul namun belum resmi diumumkan di Indonesia, Periode Kedua saat Maret 2020 - Mei 2020 saat Pandemi resmi diumumkan dan berlaku pembatasan Sosial Bersakal Besar (PSBB), dan periode Juni 2020 - Desember 2020 saat PSBB telah dilonggarkan. Lebih lanjut penelitian ini juga akan menguji bagaimana peramalan return harian saham-saham syariah saat terjadi pandemi dengan menggunakan pengukuran Simple Moving Average (SMA). Penelitian ini memberikan temuan bahwa pandemi covid-19 menyebabkan ketidakpastian diawal-awal terjadi infeksi global dan return harian saham-saham syariah mengalami pertumbuhan yang negatif sepanjang periode PSBB. Dengan diperlonggarnya PSBB maka peluang untuk terus mencatatkan pertumbuhan return harian yang positif semakin besar karena aktivitas ekonomi telah berjalan kembali. Temuan lain dalam penelitian ini juga menunjukkan bahwa pergerakan JII sedikit turun pada saat awal pemberlakuan PSBB namun terbukti tetap stabil dalam jangka menengan dan panjang.
\end{abstract}

Kata Kunci: Saham Syariah, Covid-19, Moving Average

\section{Abstract}

The Purposes of this study are to measure the effect of Covid-19 to Jakarta Islamic Index Performance into three periods. First in the period December 2019 - February 2020 which is the period in which Covid-19 has appeared but has not been officially announced in Indonesia, the Second Period is March 2020 - May 2020 when the Pandemic is officially announced and the Massive Social Distancing Announced (PSBB), and the third, the period June 2020 - December 2020 when the PSBB was relaxed. Furthermore, this study will also examine how to forecast the return of Islamic stocks during a pandemic using the Simple Moving Average (SMA) measurement. This study provides findings that the Covid-19 pandemic caused uncertainty in the early days of global infection and returned daily Islamic stocks experiencing negative return throughout the PSBB period. With the relaxation of the PSBB, the opportunity to continue to record positive daily return is even greater because economic activity has resumed. Other findings in this study also show that

\footnotetext{
${ }^{1}$ Institut Ilmu Al-Qur'an Jakarta,

Email: smuhari@iiq.ac.id
} 
the movement of the JII decreased slightly at the start of the implementation of the PSBB but proved to be stable in the medium and long term.

Keywords: Islamic Stock, Covid-19, Moving Average

\section{A. PENDAHULUAN}

Sejak kasus pertama Covid-19 di Indoensia resmi diumumkan oleh Pemerintah pada 2 Maret 2020, hingga saat akhir tahun 2020 covid-19 belum sepenuhnya mereda dan kasus yang terjadi terus meningkat. Berdasarkan data John Hopkins University per 25 Desember 2020 Covid-19 telah menginfeksi sebanyak 700.097 orang yang menyebabkan 20.847 jumlah kematian di Indonesia.

Pandemi Covid-19 juga berdampak pada sektor ekonomi dimana Kuartal-III ekonomi Indonesia terkontraksi 5,32\% dan pada kuartal-IV terkontraksi 3,49\% sehingga Indonesia resmi mengalami resesi (Badan Pusat Statistik, 2020). Hal yang sama terjadi pada Pasar Modal Indonesia dimana Indeks Harga Saham Gabungan sempat turun hingga dibawah level 5.000 pada bulan Maret saat awal kasus Covid-19 diumumkan sebelum akhirnya ditetapkan Covid-19 ditetapkan sebagai pandemi global oleh World Health Organization (WHO). Hal yang sama juga terjadi pada pasar modal syariah Indonesia dimana Indeks Jakarta Islamic Index (JII) berada di level 393 pada 24 Maret 2020 sebelum akhirnya meningkat kembali menjadi 635 pada 23 Desember 2020. Lebih lanjut kinerja JII menunjukkan perbaikan berarti seiring dengan terus meningkatnya kasus harian Covid-19 di Indonesia.

Saat ini dampak pandemi Covid-19 masih dirasakan oleh sebagian besar masyarakat karena menggangu aktivitas ekonomi termasuk di pasar modal yang didalamnya terdapat aktivitas perdagangan saham. Beberapa penelitian mengemukakan bahwa adanya pandemi berdampak pada pasar modal di berbagai negara di dunia baik negara maju dan berkembang. Penelitian yang mengukur dampak covid 19 pada aktivitas investor di pasar modal diantaranya dilakukan oleh Ahmar, A. S., \& del Val, E. B. (2020), Baek, S., Mohanty, S. K., \& Glambosky, M. (2020), Engelhardt, N., Krause, M., Neukirchen, D., \& Posch, P. N. (2020), Erdem, O. (2020), Harjoto, M. A., Rossi, F., Lee, R., \& Sergi, B. S. (2020), Haroon, O., \& Rizvi, S. A. R. (2020), Horváth, D., \& Wang, Y. L. (2020), Just, M., \& Echaust, K. (2020), Mazur, M., Dang, M., 
\& Vega, M. (2020), Okorie, D. I., \& Lin, B. (2020), Rahman, M. L., Amin, A., \& Al Mamun, M. A. (2020), Takyi, P. O., \& Bentum-Ennin, I. (2020), Topcu, M., \& Gulal, O. S. (2020), Xu, L. (2020), dan Yong, H. H. A., \& Laing, E. (2020).

Belum diketahui secara pasti kapan Pandemi Covid-19 ini berakhir, demikian juga dampaknya di pasar modal syariah Indonesia. Namun demikian, kajian kinerja pasar modal syariah pada saat sebelum dan selama pengumuman pandemi, maupun pada saat Pembatasan Sosial Berskala Besar (PSBB) dan pelonggarannya perlu untuk dilakukan agar dapat menjadi referensi dalam memahami kinerja pasar saham syariah pada saat pandemi global.

\section{B. PENELITIAN TERDAHULU}

Ahmar, A. S., \& del Val, E. B. (2020) melakukan prediksi jangka pendek kasus terkonfirmasi Covid-19 dan indeks IBEX di Spanyol dengan menggunakan metode SutteARIMA. Berdasarkan hasil metode peramalan ARIMA dan SutteARIMA, dapat disimpulkan bahwa metode SutteARIMA lebih cocok digunakan untuk menghitung ramalan harian kasus terkonfirmasi Covid-19 dan IBEX di Spanyol dibandingkan ARIMA.

Takyi, P. O., \& Bentum-Ennin, I. (2020) mengevaluasi dan mengkuantifikasi dampak jangka pendek penyakit coronavirus 2019 (COVID-19) terhadap kinerja pasar saham di tiga belas (13) negara Afrika, menggunakan data pasar saham time series harian dari 1 Oktober 2019 hingga 30 Juni 2020. Secara umum, perkiraan posterior Bayesian model ini menunjukkan bahwa, secara relatif, kinerja pasar saham di Afrika telah berkurang secara signifikan selama dan setelah terjadinya COVID-19, biasanya antara $-2,7 \%$ dan $-21 \%$. Pada tingkat heterogen, model ini menemukan bahwa 10 negara memiliki pasar sahamnya secara signifikan dan terpengaruh oleh COVID-19, sedangkan 3 negara lainnya tidak melihat dampak signifikan (atau dampak signifikan negatif yang berumur pendek) dari pandemi COVID-19. Model ini juga menemukan bahwa, dalam periode sampel kami, hampir tidak ada kemungkinan pandemi COVID-19 akan berdampak positif pada kinerja pasar saham di Afrika.

$\mathrm{Xu}$, L. (2020) menyelidiki respons dinamis dari pengembalian saham terhadap perubahan tak terduga dalam kasus COVID-19 dan ketidakpastian yang terkait dengan pandemi. Menggunakan data

\footnotetext{
$62 \mid \begin{aligned} & \text { KINERJA JAKARTA ISLAMIC INDEX } \\ & \text { DIMASA PANDEMI COVID-19 TAHUN } 2020\end{aligned}$

Syafaat Muhari
} 
transaksi saham harian dari Kanada dan AS yang menemukan ada dampak negatif dari peningkatan kasus COVID-19 di pasar saham secara umum. Selain itu, respon return saham asimetris dalam kenaikan dan penurunan kasus di Kanada. Respon Asimetri tersebut disebabkan oleh dampak negatif dari ketidakpastian tentang pandemi.

Rahman, M. L., Amin, A., \& Al Mamun, M. A. (2020) menganalisis bagaimana pasar saham Australia dalam menanggapi ketidakpastian yang diciptakan oleh pandemi COVID-19 dan apakah paket stimulus yang ditawarkan oleh Pemerintah membantu memulihkan kepercayaan di pasar. Studi ini menemukan reaksi negatif pasar saham terhadap pengumuman pandemi, namun di antara dua pengumuman terkait paket stimulus, pasar hanya bereaksi positif terhadap paket "JobKeeper". Hasil cross-sectional menunjukkan bahwa portofolio terkecil, paling tidak menguntungkan, dan bernilai lebih menderita selama pandemi. Akhirnya, ukuran dan likuiditas ditemukan sebagai pendorong signifikan dari pengembalian abnormal.

Yong, H. H. A., \& Laing, E. (2020) menganalisis reaksi pasar saham AS terhadap pengumuman Organisasi Kesehatan Dunia yang menyatakan COVID-19 sebagai pandemi global, dengan fokus pada paparan perusahaan-perusahaan global. Penelitian ini menemukan bahwa sementara eksposur internasional melalui penjualan luar negeri, aset asing, impor dan ekspor signifikan dan secara negatif terkait dengan pengembalian abnormal kumulatif standar dalam jangka pendek, efeknya berbalik dalam jangka panjang. Dalam jangka panjang, internasionalisasi berkontribusi pada perusahaan multinasional yang lebih tahan terhadap guncangan ekonomi yang disebabkan oleh COVID-19.

Horváth, D., \& Wang, Y. L. (2020) mengevaluasi kinerja model Fama-French di pasar saham AS selama acara yang dipilih dengan mempelajari model $\mathrm{R}^{2}$. Model ini menemukan bahwa pengaruh gelembung perusahaan teknologi informasi terhadap model $\mathrm{R}^{2}$ dari model pertumbuhan signifikan secara statistik. $\mathrm{R}^{2}$ dari portofolio pertumbuhan menurun dengan cepat selama krisis keuangan tahun 2008.

Baek, S., Mohanty, S. K., \& Glambosky, M. (2020) melakukan studi yang berfokus pada pemahaman perubahan rezim dari volatilitas yang lebih rendah ke yang lebih tinggi yang diidentifikasi dengan model 
Markov Switching AR. Memanfaatkan metode pemilihan fitur machine learning, indikator ekonomi dipilih untuk menjelaskan perubahan volatilitas dengan paling baik. Hasil penelitian menunjukkan bahwa volatilitas dipengaruhi oleh indikator ekonomi tertentu dan sensitif terhadap berita COVID-19. Informasi COVID-19 negatif dan positif signifikan, meskipun berita negatif lebih berdampak, namun menunjukkan bias negatif. Peningkatan signifikan dalam risiko total dan khusus diamati di semua industri, sementara perubahan risiko sistematis bervariasi di seluruh industri.

Topcu, M., \& Gulal, O. S. (2020) dalam penelitiannya menunjukkan bahwa dampak negatif pandemi di pasar saham negara berkembang secara bertahap menurun dan mulai berkurang pertengahan April. Dalam hal klasifikasi regional, dampak wabah paling tinggi di pasar negara berkembang Asia sedangkan pasar negara berkembang di Eropa mengalami yang terendah. Penelitian ini juga menemukan bahwa waktu tanggapan resmi dan ukuran paket stimulus yang disediakan oleh pemerintah penting dalam mengimbangi efek pandemi.

Just, M., \& Echaust, K. (2020) menganalisis hubungan antara return pasar saham AS (S \& P500) dan tiga indikator pasar, yaitu volatilitas tersirat, korelasi tersirat, dan likuiditas. Hal ini juga mempertimbangkan ketergantungan jangka pendek antara total kasus yang dikonfirmasi dan kematian di dua belas negara dan pergerakan pasar. Model ini menggunakan model peralihan Markov dua rezim untuk menemukan jeda struktural antara pengembalian pasar saham dan indikator pasar saham utama. Temuan menunjukkan ketergantungan erat antara pengembalian dan volatilitas tersirat dan korelasi tersirat tetapi tidak dengan likuiditas.

Mazur, M., Dang, M., \& Vega, M. (2020) menganalisis kinerja pasar saham AS selama Maret 2020 yang dipicu oleh COVID-19. Penelitian ini menemukan bahwa saham gas alam, makanan, perawatan kesehatan, dan perangkat lunak memperoleh pengembalian positif yang tinggi, sedangkan nilai ekuitas di sektor minyak bumi, real estate, hiburan, dan perhotelan turun secara dramatis. Selain itu, saham yang kalah menunjukkan volatilitas asimetris yang ekstrim yang berkorelasi negatif dengan pengembalian saham. Perusahaan bereaksi dalam berbagai cara berbeda terhadap guncangan pendapatan COVID-19. 
Harjoto, M. A., Rossi, F., Lee, R., \& Sergi, B. S. (2020) menggunakan data harian frekuensi tinggi di 53 negara berkembang dan 23 negara maju dari 14 Januari hingga 20 Agustus 2020, penelitian ini menemukan bahwa kasus COVID-19 dan kematian berdampak negatif pada pengembalian saham dan meningkatkan volatilitas dan volume perdagangan. Kasus dan kematian memengaruhi pengembalian dan volatilitas saham di pasar negara berkembang, sementara hanya kasus COVID-19 yang memengaruhi pengembalian saham, volatilitas, dan volume perdagangan di pasar negara maju. Kasus COVID-19 dan kematian terkait dengan pengembalian, volatilitas, dan volume perdagangan untuk negara-negara berkembang selama meningkatnya infeksi COVID-19 (sebelum April 2020), sementara kasus dan tingkat kematian terkait dengan pengembalian, volatilitas, dan volume perdagangan di negara maju selama penyebaran stabil (pasca-April 2020). Oleh karena itu, investor pasar negara berkembang tampaknya bereaksi terhadap kasus COVID-19 dan tingkat kematian secara berbeda dari yang ada di pasar negara maju selama dua periode infeksi COVID-19 yang berbeda.

Erdem, O. (2020) menganalisis apakah ada hubungan antara kebebasan negara dan pergerakan pasar sahamnya dalam menanggapi pengumuman Covid-19. Mempertimbangkan bahwa negara-negara yang lebih bebas mengumumkan jumlah kasus dan korban tewas yang dikonfirmasi lebih tinggi daripada yang lain, studi ini secara khusus memperhatikan bagaimana pasar bereaksi terhadap pengumuman pandemi negara-negara ini. Dengan menggunakan indeks pasar saham yang luas dari 75 negara bersama dengan nomor tol virus korona mereka, hasilnya menunjukkan bahwa pasar secara signifikan dipengaruhi secara negatif oleh pandemi: pengembalian indeks menurun dan volatilitas meningkat. Namun, efek dari pertumbuhan jumlah kasus per juta pada return saham hampir tiga kali lipat dari pertumbuhan jumlah kematian per-juta.

Haroon, O., \& Rizvi, S. A. R. (2020) menggunakan data perdagangan tingkat transaksi harian untuk menunjukkan bahwa investor secara signifikan meningkatkan aktivitas perdagangan mereka saat pandemi COVID-19 terungkap. Investor, rata-rata, meningkatkan deposit pada broker mereka dan membuka lebih banyak akun baru. Intensitas perdagangan mingguan rata-rata meningkat 13,9\% karena 
jumlah kasus COVID-19 berlipat ganda. Peningkatan dalam perdagangan terutama terjadi pada investor laki-laki dan usia yang lebih tua serta mempengaruhi perdagangan saham dan indeks. Setelah Dow Jones turun 9,99\% pada 12 Maret, investor secara signifikan mengurangi penggunaan leveragenya.

Engelhardt, N., Krause, M., Neukirchen, D., \& Posch, P. N. (2020) menganalisis apakah kepercayaan memengaruhi volatilitas pasar saham global selama pandemi COVID-19. Dengan menggunakan sampel 47 pasar saham nasional, penelitian ini menemukan volatilitas pasar saham secara signifikan lebih rendah di negara-negara dengan kepercayaan tinggi (sebagai reaksi terhadap pengumuman kasus COVID-19). Baik kepercayaan pada sesama warga maupun pada pemerintah negara adalah sangat penting.

Okorie, D. I., \& Lin, B. (2020) menganalisis penularan fraktal dari pandemi COVID-19 di pasar saham. Informasi pasar saham dari 32 negara ekonomi maju yang terkena dampak virus corona (per 31 Maret 2020) diambil sampelnya untuk analisis wabah COVID-19 ex-ante dan ex-post menggunakan Detrended Moving Cross-Correlation Analysis (DMCA) dan Detrended Cross-Correlation Analysis (DCCA). Hasilnya mengkonfirmasi penularan fraktal dari pandemi COVID-19 di pasar saham. Lebih jauh lagi, efek penularan fraktal ini menghilang seiring waktu (dalam jangka menengah dan panjang) untuk pengembalian dan volatilitas pasar saham.

\section{METODE PENELITIAN}

Jenis penelitian yang digunakan peneliti dalam penelitian ini bersifat deskriptif dengan pendekatan kuantitatif. Penelitian deskriptif adalah "Penelitian yang dilakukan untuk memberi gambaran yang lebih detail mengenai suatu gejala atau fenomena" (Prasetyo, 2007:42). Pendekatan kuantitatif merupakan suatu metode dimana data penelitian berupa angka-angka dan analisis menggunakan statistik (Sugiyono, 2010:7).

Populasi dalam penelitian ini adalah saham-saham yang termasuk dalam Jakarta Islamic Index (JII) periode Desember 2019 hingga Desember 2020 berdasarkan Daftar Efek Syariah (DES) yang dirilis oleh Otoritas Jasa Keuangan Tahun 2020. DES dirilis oleh OJK sebanyak dua kali setahun. Dari 30 saham yang terindex JII hanya 23 emiten yang yang dijadikan sebagai sampel sebab masih konsisten dalam daftar JII selama dua semester berturut-turut. Teknik pengambilan sampel dalam 
penelitian ini adalah puposive sampling. Purposive sampling merupakan teknik sampling yang didasarkan pada tujuan dan pertimbangan tertentu. Pertimbangan yang digunakan yaitu saham perusahaan selalu bertahan dalam indeks JII (bukan termasuk saham baru dalam indeks JII) pada periode Desember 2019 hingga Desember 2020. Adapun emiten JII yang dijadikan sampel adalah sebagai berikut:

Table 1. Sampel dalam Penelitian

\begin{tabular}{c|c|l}
\hline No & Kode Emiten & \multicolumn{1}{|c}{ Emiten } \\
\hline 1 & ADRO & PT Adaro Energy Tbk \\
\hline 2 & AKRA & PT AKR Corporindo, Tbk \\
\hline 3 & ANTM & PT Aneka Tambang Tbk \\
\hline 4 & ASII & PT Astra International Tbk \\
\hline 5 & BRPT & PT Barito Pacific Tbk \\
\hline 6 & BTPS & PT Bank BTPN Syariah Tbk \\
\hline 7 & CPIN & PT Charoen Popkhan Indonesia Tbk \\
\hline 8 & CTRA & PT Ciputra Development Tbk \\
\hline 9 & ERAA & PT Erajaya Swasembada Tbk \\
\hline 10 & EXCL & PT XL Axiata Tbk \\
\hline 11 & ICBP & PT Indofood CBP Sukses Makmur \\
\hline 12 & INCO & PT Vale Indonesia Tbk \\
\hline 13 & INDF & PT Indofood Sukses Makmur Tbk \\
\hline 14 & INTP & PT Indocement Tunggal Prakarsa Tbk \\
\hline 15 & JPFA & PT Japfa Comfeed Indoensia Tbk \\
\hline 16 & JSMR & PT Jasa Marga (Persero) Tbk \\
\hline 17 & KLBF & PT Kalbe Farma Tbk \\
\hline 18 & PTBA & PT Bukit Asam Tbk \\
\hline 19 & SCMA & PT Surya Citra Media Tbk \\
\hline & & \\
\hline 19 & \\
\hline 19 & \\
\hline 14
\end{tabular}


al-Mizan, Vol. 5, No.1, hlm. 60-76, Februari 2021,

P.ISSN : 2085-6792, E.ISSN : 2656-7164

\begin{tabular}{c|c|l}
\hline No & Kode Emiten & \multicolumn{1}{|c}{ Emiten } \\
\hline 20 & TLKM & PT Telekomunikasi Indonesia (Persero) \\
\hline 21 & UNTR & PT United Tractors Tbk \\
\hline 22 & UNVR & PT Unilever Indonesia Tbk \\
\hline 23 & WIKA & PT Wijaya Karya (Persero) Tbk \\
\hline
\end{tabular}

Sumber: Daftar Efek Syariah OJK, 2020

Sumber data harga penutupan saham harian diperoleh melalui Yahoo Finance dimana data yang diambil merupakan data harga saham penutupan. Adapun analisis data akan menggunakan statistik deskriptif untuk mengukur return harian dari saham-saham JII, pengukuran yang digunakan adalah pengukuran Mean, Standar Deviasi, Minimum, dan Maximum. Pembagian pengukuran ini dibagi menjadi tiga periode, yakni pada periode Desember 2019 - Februari 2020 yang merupakan periode dimana Covid-19 sudah muncul namun belum resmi diumumkan di Indonesia, Periode Kedua saat Maret 2020 - Mei 2020 saat Pandemi resmi diumumkan dan berlaku PSBB, dan periode Juni 2020 - Desember 2020 saat PSBB telah dilonggarkan. Lebih lanjut penelitian ini juga akan menguji bagaimana peramalan return harian saham-saham syariah saat terjadi pandemi dengan menggunakan pengukuran Simple Moving Average (SMA) pada interval 8, 25, dan 125 dimana angka tersebut mengikuti bilangan fibonacci.

D. HASIL DAN PEMBAHASAN

Tabel 2. Rata-rata Return Saham JII Sebelum Pandemi Covid-19

Desember 2019 - Februari 2020

\begin{tabular}{c|c|r|r|c}
\hline \multirow{2}{*}{} & \multicolumn{4}{|c}{ Pre-Covid } \\
\cline { 2 - 5 } & Mean & Std. Dev. & \multicolumn{1}{c}{ Min. } & Max. \\
\hline JII & $-0.48 \%$ & $1.03 \%$ & $-2.62 \%$ & $1.23 \%$ \\
\hline ADRO & $-0.66 \%$ & $2.65 \%$ & $-6.80 \%$ & $5.12 \%$ \\
\hline ANTM & $-0.77 \%$ & $2.25 \%$ & $-5.36 \%$ & $4.12 \%$ \\
\hline ASII & $-0.47 \%$ & $1.99 \%$ & $-7.14 \%$ & $3.61 \%$ \\
\hline BRPT & $-0.90 \%$ & $2.99 \%$ & $-8.42 \%$ & $6.45 \%$ \\
\hline BTPS & $-0.22 \%$ & $2.97 \%$ & $-6.93 \%$ & $7.54 \%$ \\
\hline
\end{tabular}

68

68 DIMASA PANDEMI COVID-19 TAHUN 2020

Syafaat Muhari 


\begin{tabular}{c|c|r|r|l}
\hline \multirow{2}{*}{} & \multicolumn{4}{|c}{ Pre-Covid } \\
\cline { 2 - 5 } CPIN & Mean & Std. Dev. & \multicolumn{1}{c}{ Min. } & Max. \\
\hline CTRA & $-0.34 \%$ & $3.13 \%$ & $-6.77 \%$ & $8.40 \%$ \\
\hline ERAA & $0.01 \%$ & $2.23 \%$ & $-4.55 \%$ & $5.68 \%$ \\
\hline EXCL & $-0.52 \%$ & $3.09 \%$ & $-6.45 \%$ & $7.30 \%$ \\
\hline ICBP & $-0.22 \%$ & $1.42 \%$ & $-6.32 \%$ & $2.22 \%$ \\
\hline INCO & $-0.83 \%$ & $2.31 \%$ & $-8.71 \%$ & $3.52 \%$ \\
\hline INDF & $-0.43 \%$ & $2.02 \%$ & $-8.79 \%$ & $3.55 \%$ \\
\hline INTP & $-0.60 \%$ & $2.33 \%$ & $-4.35 \%$ & $6.08 \%$ \\
\hline JPFA & $-0.22 \%$ & $2.19 \%$ & $-5.71 \%$ & $6.05 \%$ \\
\hline JSMR & $-0.29 \%$ & $1.78 \%$ & $-4.60 \%$ & $3.23 \%$ \\
\hline KLBF & $-0.61 \%$ & $2.02 \%$ & $-5.61 \%$ & $5.38 \%$ \\
\hline PTBA & $-0.31 \%$ & $2.38 \%$ & $-5.49 \%$ & $4.12 \%$ \\
\hline SCMA & $-0.45 \%$ & $2.81 \%$ & $-6.02 \%$ & $8.59 \%$ \\
\hline TLKM & $-0.31 \%$ & $1.20 \%$ & $-2.41 \%$ & $2.10 \%$ \\
\hline UNTR & $-0.52 \%$ & $1.88 \%$ & $-5.55 \%$ & $4.34 \%$ \\
\hline UNVR & $-0.43 \%$ & $1.60 \%$ & $-4.55 \%$ & $2.86 \%$ \\
\hline WIKA & $-0.08 \%$ & $2.20 \%$ & $-4.34 \%$ & $6.13 \%$ \\
\hline S & & &
\end{tabular}

Sumber: Data diolah

Data diatas menggambarkan perkembangan return harian saham JII sebelum Pandemi Covid-19 resmi diumumkan di Indonesia. Pada tabel diatas dapat dilihat bahwa rata-rata return harian JII adalah sebesar $-0,48 \%$ yang berarti return harian JII negatif selama periode tersebut. Adapun volatilitas return saham Jakarta Islamic Index (JII) cukup tinggi dengan standar deviasi berada di angka 1,3\%. Dapat dilihat bahwa hampir seluruh emiten JII mengalami pertumbuhan yang negatif kecuali pada saham PT. Erajaya Swasembada, Tbk (ERAA) dimana pertumbuhan harian rata-rata sebesar $0.01 \%$. Adapun saham yang mengalami pertumbuhan negatif paling dalam adalah PT. Barito Pacific, Tbk (BRPT) dengan nilai pertumbuhan harian rata-rata sebesar $-0.90 \%$. 
al-Mizan, Vol. 5, No.1, hlm. 60-76, Februari 2021,

P.ISSN : 2085-6792, E.ISSN : 2656-7164

Tabel 3. Rata-rata Return Saham JII Selama Masa PSBB

Maret 2020 - Mei 2020

\begin{tabular}{|c|c|c|c|c|}
\hline & \multicolumn{4}{|c|}{ PSBB } \\
\hline & Mean & Std. Dev. & Min. & Max. \\
\hline JII & $-0.05 \%$ & $3.68 \%$ & $-7.84 \%$ & $12.81 \%$ \\
\hline ADRO & $0.09 \%$ & $5.89 \%$ & $-13.99 \%$ & $15.50 \%$ \\
\hline ANTM & $0.01 \%$ & $5.33 \%$ & $-15.10 \%$ & $16.38 \%$ \\
\hline ASII & $-0.14 \%$ & $4.78 \%$ & $-11.45 \%$ & $12.71 \%$ \\
\hline BRPT & $0.82 \%$ & $7.72 \%$ & $-12.89 \%$ & $20.83 \%$ \\
\hline BTPS & $-0.20 \%$ & $7.45 \%$ & $-7.58 \%$ & $24.66 \%$ \\
\hline CPIN & $0.16 \%$ & $5.37 \%$ & $-11.56 \%$ & $16.63 \%$ \\
\hline CTRA & $-0.68 \%$ & $5.96 \%$ & $-14.48 \%$ & $25.00 \%$ \\
\hline ERAA & $-0.25 \%$ & $6.32 \%$ & $-14.86 \%$ & $22.22 \%$ \\
\hline EXCL & $0.18 \%$ & $6.28 \%$ & $-9.09 \%$ & $24.82 \%$ \\
\hline ICBP & $-0.33 \%$ & $3.74 \%$ & $-6.98 \%$ & $14.46 \%$ \\
\hline INCO & $0.38 \%$ & $5.78 \%$ & $-13.23 \%$ & $17.76 \%$ \\
\hline INDF & $-0.11 \%$ & $4.70 \%$ & $-8.27 \%$ & $18.32 \%$ \\
\hline INTP & $-0.17 \%$ & $6.28 \%$ & $-18.88 \%$ & $19.95 \%$ \\
\hline JPFA & $-0.62 \%$ & $5.22 \%$ & $-16.25 \%$ & $14.77 \%$ \\
\hline JSMR & $-0.32 \%$ & $5.65 \%$ & $-13.24 \%$ & $14.58 \%$ \\
\hline KLBF & $0.36 \%$ & $4.69 \%$ & $-7.69 \%$ & $14.83 \%$ \\
\hline РTBA & $-0.06 \%$ & $6.10 \%$ & $-16.99 \%$ & $21.21 \%$ \\
\hline SCMA & $-0.05 \%$ & $5.51 \%$ & $-12.90 \%$ & $18.11 \%$ \\
\hline TLKM & $-0.10 \%$ & $4.06 \%$ & $-6.96 \%$ & $13.74 \%$ \\
\hline UNTR & $0.02 \%$ & $4.98 \%$ & $-8.67 \%$ & $17.86 \%$ \\
\hline UNVR & $0.32 \%$ & $4.55 \%$ & $-6.92 \%$ & $19.38 \%$ \\
\hline WIKA & $-0.71 \%$ & $6.82 \%$ & $-18.21 \%$ & $24.73 \%$ \\
\hline
\end{tabular}

Sumber: Data diolah

Data diatas menggambarkan perkembangan return harian saham JII Setelah Covid-19 resmi diumumkan di Indonesia dan berlaku Pembatasan Sosial Berskala Besar (PSBB) di Indonesia. Pada tabel diatas dapat dilihat bahwa rata-rata return harian JII adalah sebesar $-0,05 \%$ yang berarti return harian JII negatif selama periode tersebut namun 
sudah lebih baik dibandingkan dengan periode sebelumnya. Hal ini mengingat investor telah mendapat kepastian terkait dengan masuknya covid-19 di Indonesia sehingga langkah-langkah preventif dapat segera dilakukan. Adapun volatilitas return saham Jakarta Islamic Index (JII) semakin tinggi dibandingkan dengan dengan standar deviasi periode sebelumnya berada di angka 3,68\%. Dapat dilihat bahwa hampir seluruh emiten-emiten JII berhasil membukukan pertumbuhan positif dengan pertumbuhan paling tinggi ditunjukkan oleh PT. Vale Indonesia (INCO) dan PT. Kalbe Farma (KLBF) dengan angka rata-rata return saham harian sebesar $0,38 \%$ dan $0,36 \%$ yang didorong oleh tingginya kebutuhan alat kesehatan dan obat-obatan dalam rangka mengatasi covid-19. Adapun saham yang mengalami pertumbuhan negatif paling dalam adalah PT. Ciputra Development (CTRA) dengan nilai pertumbuhan harian rata-rata sebesar $-0.68 \%$ mengingat masih lesunya pasar perumahan mengingat lebih banyak konsumen di Indonesia yang lebih memprioritaskan kebutuhan primer dan lebih banyak yang menggunakan dananya untuk berjaga-jaga.

Tabel 4. Rata-rata Return Saham JII Setelah PSBB Dilonggarkan Juni 2020 - Desember 2020

\begin{tabular}{c|c|r|r|r}
\hline \multirow{2}{*}{} & \multicolumn{4}{|c}{ Post-PSBB } \\
\cline { 2 - 5 } & Mean & Std. Dev. & \multicolumn{1}{c}{ Min. } & \multicolumn{1}{c}{ Max. } \\
\hline JII & $0.17 \%$ & $1.33 \%$ & $-5.01 \%$ & $3.49 \%$ \\
\hline ADRO & $0.29 \%$ & $2.81 \%$ & $-6.78 \%$ & $6.58 \%$ \\
\hline ANTM & $1.04 \%$ & $4.15 \%$ & $-6.92 \%$ & $24.84 \%$ \\
\hline ASII & $0.22 \%$ & $2.38 \%$ & $-6.94 \%$ & $5.91 \%$ \\
\hline BRPT & $0.01 \%$ & $3.50 \%$ & $-6.88 \%$ & $15.33 \%$ \\
\hline BTPS & $0.24 \%$ & $2.83 \%$ & $-6.85 \%$ & $13.11 \%$ \\
\hline CPIN & $0.17 \%$ & $2.62 \%$ & $-6.72 \%$ & $7.88 \%$ \\
\hline CTRA & $0.51 \%$ & $3.55 \%$ & $-6.87 \%$ & $14.39 \%$ \\
\hline ERAA & $0.44 \%$ & $2.47 \%$ & $-6.93 \%$ & $8.43 \%$ \\
\hline EXCL & $0.12 \%$ & $2.81 \%$ & $-6.96 \%$ & $8.37 \%$ \\
\hline ICBP & $0.15 \%$ & $1.73 \%$ & $-6.60 \%$ & $7.80 \%$ \\
\hline INCO & $0.53 \%$ & $2.79 \%$ & $-5.49 \%$ & $9.89 \%$ \\
\hline INDF & $0.17 \%$ & $1.81 \%$ & $-4.29 \%$ & $4.81 \%$ \\
\hline
\end{tabular}




\begin{tabular}{c|c|r|r|r}
\hline \multirow{2}{*}{} & \multicolumn{4}{|c}{ Post-PSBB } \\
\cline { 2 - 5 } & Mean & Std. Dev. & \multicolumn{1}{c}{ Min. } & \multicolumn{1}{c}{ Max. } \\
\hline INTP & $0.19 \%$ & $2.86 \%$ & $-6.87 \%$ & $11.57 \%$ \\
\hline JPFA & $0.50 \%$ & $3.26 \%$ & $-6.99 \%$ & $18.88 \%$ \\
\hline JSMR & $0.25 \%$ & $2.63 \%$ & $-6.86 \%$ & $8.43 \%$ \\
\hline KLBF & $0.08 \%$ & $1.87 \%$ & $-4.82 \%$ & $6.42 \%$ \\
\hline PTBA & $0.36 \%$ & $2.49 \%$ & $-6.94 \%$ & $8.54 \%$ \\
\hline SCMA & $0.66 \%$ & $2.79 \%$ & $-6.87 \%$ & $11.57 \%$ \\
\hline TLKM & $0.11 \%$ & $2.23 \%$ & $-6.65 \%$ & $7.69 \%$ \\
\hline UNTR & $0.47 \%$ & $2.80 \%$ & $-6.98 \%$ & $10.45 \%$ \\
\hline UNVR & $0.00 \%$ & $1.23 \%$ & $-3.33 \%$ & $4.52 \%$ \\
\hline WIKA & $0.53 \%$ & $3.32 \%$ & $-6.72 \%$ & $10.75 \%$ \\
\hline
\end{tabular}

Sumber: Data diolah

Data diatas menggambarkan perkembangan return harian saham JII Setelah PSBB Covid-19 dilonggarkan dan banyak perusahaan melanjutkan usahanya meskipun dengan skala terbatas. Pada tabel diatas dapat dilihat bahwa rata-rata return harian JII adalah sebesar $0,17 \%$ yang berarti return harian JII positif selama periode tersebut yang sudah lebih baik dibandingkan dengan dua periode sebelumnya. Hal ini mengingat investor telah mendapat kepastian terkait dengan kembali berlangsungnya aktivitas ekonomi meskipun dengan skala terbatas dan dengan menerapkan protokol kesehatan. Adapun volatilitas return saham Jakarta Islamic Index (JII) semakin rendah dibandingkan dengan dengan standar deviasi pada periode sebelumnya berada di angka 1,33\%. Dapat dilihat bahwa seluruh emiten-emiten JII berhasil membukukan pertumbuhan positif dengan pertumbuhan paling tinggi ditunjukkan oleh PT. Aneka Tambang (ANTM) sebesar 1,04\% yang didorong oleh tingginya permintaan emas sebagai sarana investasi dan penyimpan kekayaan yang aman selama pandemi covid-19. Dapat dilihat bahwa kinerja saham-saham syariah mulai membukukan kinerja harian yang positif.

Adapun hasil Moving Average (MA) dari pergerakan indeks pasar saham syariah di JII maupun pada saham-saham syariah dapat dilihat pada gambar berikut: 


\section{Gambar 1. Moving Average (MA) Pergerakan Jakarta Islamic Index}

(JII)

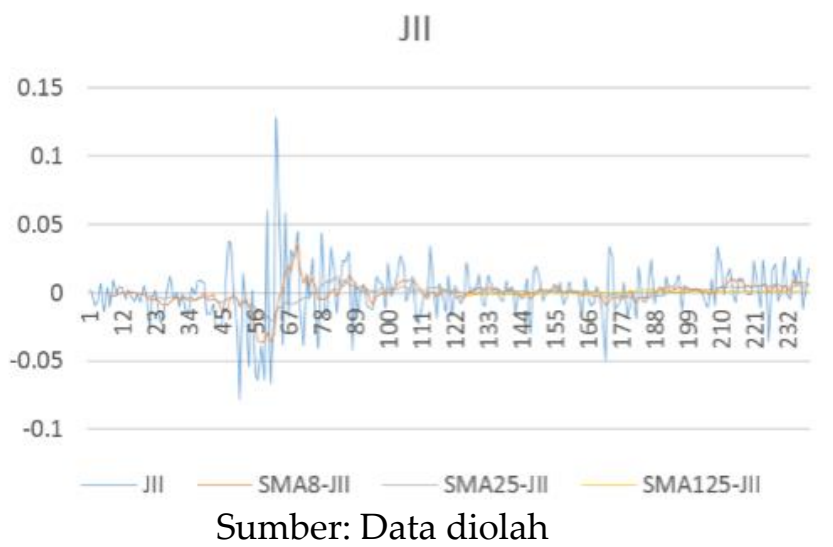

Pada gambar 1 diatas dapat digambarkan Simple Moving Average (SMA) pada interval 8, 25, dan 125 untuk pergerakan indeks JII. Dapat dilihat bahwa pada masa pengumuman kasus pertama di Indonesia SMA 8, 25, dan 125 menunjukkan volatilitas yang tajam dan semakin stabil saat PSBB di Indonesia resmi diperlonggar. Kestabilan itu dapat dilihat pada SMA 25 dan SMA 125 yang menunjukkan bahwa setelah PSBB diperlonggar Indeks saham syariah (JII) telah stabil untuk jangka panjang meskipun dalam jangka pendek masih sering terjadi volatilitas namun masih dalam taraf normal karena masih dalam kisaran $-0,05 \%$ dan $0.05 \%$.

Pada gambar 2 dapat digambarkan Simple Moving Average (SMA) pada interval 8, 25, dan 125 untuk pergerakan indeks sahamsaham syariah. Dapat dilihat bahwa pada masa pengumuman kasus pertama di Indonesia SMA 8, 25, dan 125 menunjukkan volatilitas pegerakan saham-saham syariah yang tajam dan semakin stabil saat PSBB di Indonesia resmi diperlonggar. 
al-Mizan, Vol. 5, No.1, hlm. 60-76, Februari 2021,

P.ISSN : 2085-6792, E.ISSN : 2656-7164

\section{Gambar 2. Moving Average (MA) Pergerakan Saham-saham JII}
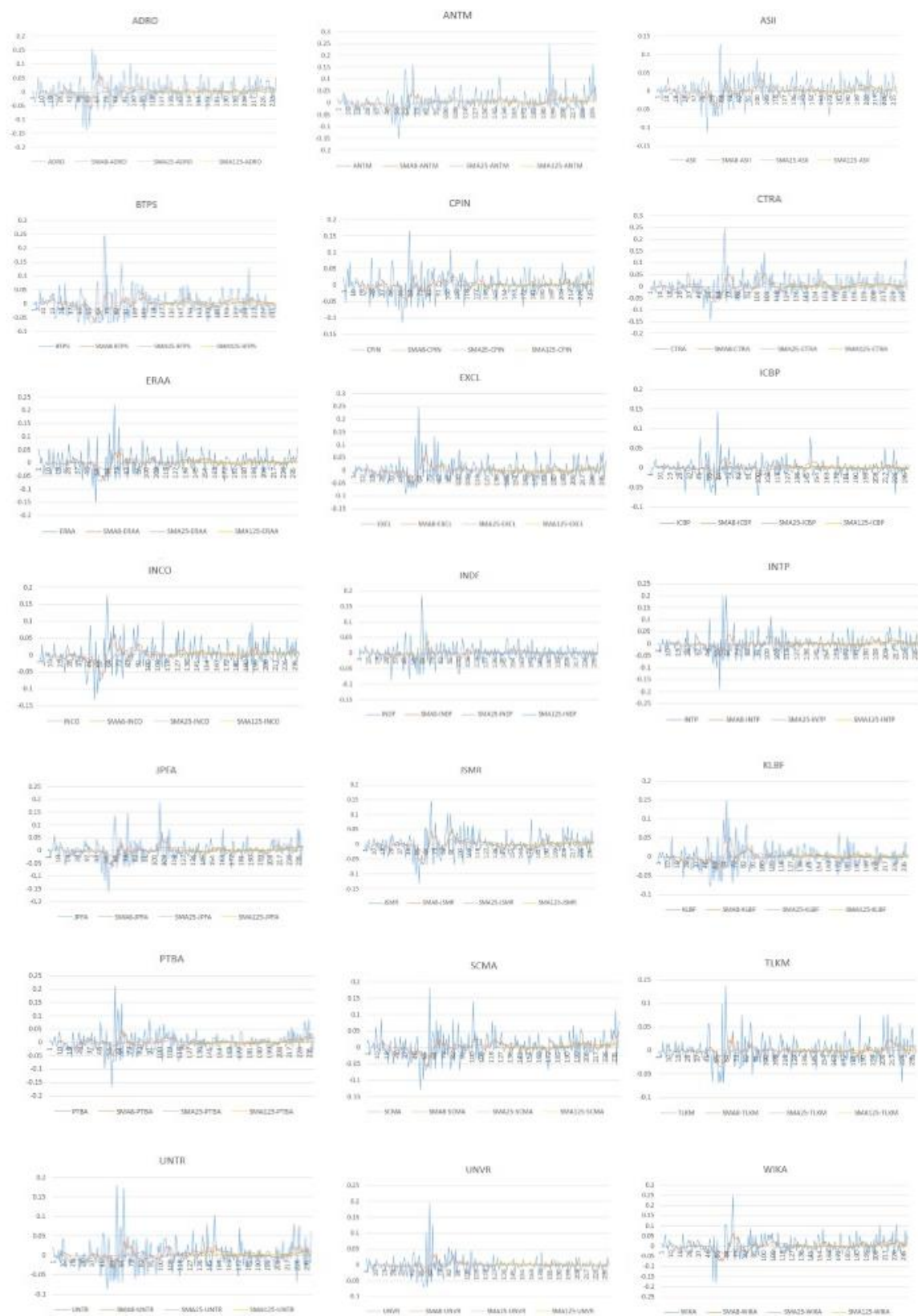

Sumber: Data diolah

\footnotetext{
$74 \mid \begin{aligned} & \text { KINERJA JAKARTA ISLAMIC INDEX } \\ & \text { DIMASA PANDEMI COVID-19 TAHUN } 2020\end{aligned}$

Syafaat Muhari
} 
Kestabilan itu dapat dilihat pada SMA 25 dan SMA 125 yang menunjukkan bahwa setelah PSBB diperlonggar saham-saham syariah yang terdaftar di JII telah stabil untuk jangka panjang meskipun dalam jangka pendek masih sering terjadi volatilitas namun masih dalam taraf normal karena masih dalam berkisara antara $-0,05 \%$ dan $0.05 \%$.

\section{E. KESIMPULAN}

Penelitian ini memberikan temuan bahwa pandemi Covid-19 menyebabkan ketidakpastian diawal-awal terjadi infeksi global dan return harian saham-saham syariah mengalami pertumbuhan yang negatif sepanjang periode PSBB. Dengan diperlonggarnya PSBB maka peluang untuk terus mencatatkan pertumbuhan return harian yang positif semakin besar karena aktivitas ekonomi telah berjalan kembali. Temuan lain dalam penelitian ini juga menunjukkan bahwa pergerakan JII sedikit turun pada saat awal pemberlakuan PSBB namun teerbukti tetap stabil dalam jangka menengan dan panjang.

\section{DAFTAR PUSTAKA}

Ahmar, A. S., \& del Val, E. B. (2020). SutteARIMA: Short-term forecasting method, a case: Covid-19 and stock market in Spain. Science of The Total Environment, 138883.

Baek, S., Mohanty, S. K., \& Glambosky, M. (2020). COVID-19 and stock market volatility: An industry level analysis. Finance Research Letters, 37, 101748.

Engelhardt, N., Krause, M., Neukirchen, D., \& Posch, P. N. (2020). Trust and stock market volatility during the COVID-19 crisis. Finance Research Letters, 101873.

Erdem, O. (2020). Freedom and stock market performance during Covid-19 outbreak. Finance Research Letters.

Harjoto, M. A., Rossi, F., Lee, R., \& Sergi, B. S. (2020). How Do Equity Markets React to COVID-19? Evidence from Emerging and Developed Countries. Journal of Economics and Business, 105966.

Haroon, O., \& Rizvi, S. A. R. (2020). COVID-19: Media coverage and financial markets behavior-A sectoral inquiry. Journal of Behavioral and Experimental Finance, 100343.

Horváth, D., \& Wang, Y. L. (2020). The examination of Fama-French Model during the Covid-19. Finance Research Letters, 101848. 
Just, M., \& Echaust, K. (2020). Stock market returns, volatility, correlation and liquidity during the COVID-19 crisis: Evidence from the Markov switching approach. Finance Research Letters, 37, 101775.

Mazur, M., Dang, M., \& Vega, M. (2020). COVID-19 and the march 2020 stock market crash. Evidence from S\&P1500. Finance Research Letters, 101690.

Okorie, D. I., \& Lin, B. (2020). Stock Markets and the COVID-19 Fractal Contagion Effects. Finance Research Letters, 101640.

Prasetyo, A. (2019). Wakaf saham dalam Meningkatkan Investasi Saham Syariah di Indonesia. Majalah Ekonomi, Vol. 24, No.2, 204210.

Rahman, M. L., Amin, A., \& Al Mamun, M. A. (2020). The COVID-19 outbreak and stock market reactions: Evidence from Australia. Finance Research Letters, 101832.

Sugiyono. (2010). Metode Penelitian Kuantitatif, Kualitatif dan RED. Bandung: Alfabeta.

Takyi, P. O., \& Bentum-Ennin, I. (2020). The impact of COVID-19 on stock markets performance in Africa: A Bayesian Structural Time Series Approach. Journal of Economics and Business, 105968.

Topcu, M., \& Gulal, O. S. (2020). The impact of COVID-19 on emerging stock markets. Finance Research Letters, 36, 101691.

$\mathrm{Xu}$, L. (2020). Stock Return and the COVID-19 pandemic: Evidence from Canada and the US. Finance Research Letters, 101872.

Yong, H. H. A., \& Laing, E. (2020). Stock market reaction to COVID-19: Evidence from US Firms' International exposure. International Review of Financial Analysis, 101656. 